\title{
古典籍説明文からのドメイン知識の抽出 \\ Extraction of Domain Knowledge from the Explanations of Japanese Classics
}

\author{
長塚 隆*, 神門典子 \\ Takashi Nagatsuka, Noriko Kando
}

\section{${ }^{*} 1$ 鶴見大学}

Dept. of Library, Archival and Information Studies, Tsurumi University,Tsurumi 2-1-3, Tsurumi-ku, Yokohama, Japan 230-8501Ｅ-mail:nagatsuka-t@tsurumi-u.ac.jp

2 国立情報学研究所

National Institute of Informatics, 2-1-2 Hitotsubashi, Chiyoda-ku, Tokyo, Japan 101-8430Ｅ-mail:kando@nii.ac.jp

\begin{abstract}
鶴見大学図書館で公開している「古典籍」の説明文を対象にメタデータの分析を行い、抽出したメタデ 一タをグループ化した。さらに、基本的な古典籍の形態である「写本」、版本」、「切れ」、および「その他 の資料」に分け、メタデータの違いについて比較したところそれぞれの古典籍の形態が反映されているこ とが明らかとなった。古典籍説明文について、ドメイン知識の視点から整理を試みた。
\end{abstract}

The metadata elements were extracted from the explanations of Japanese Classics on the web of Tsurumi University Library. They were divided into several groups and compared among four types of Japanese Classics, the manuscript, the printed book, the detached segment, and the other. It presents a clear difference of the metadata elements among four types of Japanese Classics. We discussed the difference of them from an aspect of domain knowledge.

キーワード:古典籍, 説明文, ドメイン知識, オントロジ, メタデータ, Japanese Classics, explanation, domain knowledge, ontology, metadata

\section{1 はじめに}

文化遺産をデジタル化し、インターネットで 公開するさいに、多様な文化遺産に関する情 報により効率的にアクセスできるための試みが なされている。例えば、博物館情報を用いて複 合的メタデータスキーマを構築する手法につ いての検討 ${ }^{1}$ 、文化遺産のメタデータセットに 従ってデータを分類する手法について研究し 意味論的な相互運用の管理に関するデータ 分類管理についての検討 ${ }^{2}$ 、あるいは、木下ら による民俗学研究資料の電子化を行い民俗
学分野に特化したシソーラスとOntologyの関 連性についての検討 ${ }^{3}$ など、様々な試みがなさ れている。

また、最近では、文化遺産をデジタル化しイ ンターネットで公開に際して、専門家により該 当の文化遺産を紹介する説明文を付与するケ 一スが増加している。しかし、多くの説明文は その分野についての専門的な知識を前提とし ているものが多い。

本報告では、江戸時代末までに日本で著さ れた古い書物、いわゆる「古典籍」の説明文に ついてどのようなメタデータを付与すべきかを 
検討し、自動的にメタデータを付与するための 要件について考察した。

\section{2 古典籍の説明文情報}

古典籍については、様々な角度から多くの 研究がなされている。古典籍についての書誌 情報データベースも作成され、メタデータもそ れぞれのデータベースの特徵にあわせて付与 されている。

一方で、古典籍の一般への理解や普及な どのために、大学、研究所や博物館などで多 くの展示会が開催されている。これらの展示会 では展示品を広く理解してもらうために、作品 を紹介する説明文が作成されることが多くなっ ている(表1)。

表1 Webで提供される古典籍データベースと古 典籍説明文

\begin{tabular}{|c|c|c|c|}
\hline 利用の用途 & 区分 & 提供名称 & 提供機関 \\
\hline \multirow{8}{*}{ 専門家向け } & \multirow{2}{*}{ 書誌·目録 } & NDL-OPAC & 国立国会图書館 \\
\hline & & 昌本古典籍総合目録 & \multirow{2}{*}{ 国文学研究資料館 } \\
\hline & \multirow{2}{*}{ 書誌·目録·画像 } & 日本古典資料調査データベース & \\
\hline & & 古典籍総合データベース & 早稲田大学図書館 \\
\hline & 書誌·目録·内容 & 呄典籍内容記述的データベース & 名古屋大学図書館 \\
\hline & \multirow{3}{*}{ 書誌·画像 } & & 東京国立博物館 \\
\hline & & 収蔵品データベース & 京都国立博物館 \\
\hline & & 奈良国立博物館所蔵写真検索システム & 奈良国立博物館 \\
\hline \multirow{6}{*}{ 一般向け } & |説明文 & 貴重書展 & 鶴見大学図書館 \\
\hline & \multirow{6}{*}{ |説明文·画像 } & 文化遺産オンライン & 文化序 \\
\hline & & 貴重書展 & 鶴見大学図書館 \\
\hline & & 鶴見大学コレクション & Global Memory \\
\hline & & 館蔵品百選 & 名古屋市立博物館 \\
\hline & & 名品紹介 & 奈良国立博物館 \\
\hline 子供向け & & お子様向I+Dictionary & 京都国立博物館 \\
\hline
\end{tabular}

「古典籍」についての書誌情報は、表 1 にあ るように古典籍を所蔵している国会図書館や 大学・研究機関・博物館・美術館などで、図書 の目録が作成され、インターネットで公開され ている。

これらの中には国文学研究資料館の「日本 古典資料調査データベース」や早稲田大学図 書館の「古典籍総合データベース」のように、 目録情報だけでなく書物の画像情報とあわせ て提供しているところもある。

また、名古屋大学図書館では個々の古典 籍の内容も記述する「古典籍内容記述的デー タベース」を提供している。この他に博物館や 美術館では、東京国立博物館の「館蔵品一 覧」、京都国立博物館「収蔵品データベー ス」、奈良国立博物館「所蔵写真検索システ
ム」などが所蔵品の書誌と画像を提供してい る。

最近では、これらの専門的なメタデータ情報 の提示だけでなく、古典籍の一般への理解や 普及などのために、大学、研究所や博物館な どで多くの展示会が開催されている。これらの 展示会では展示品を広く理解してもらうために、 作品を紹介寸る説明文が作成され、インター ネットで公開されることも多くなっている。

インターネットで公開されている古典籍の説 明文は、まだそれほど多くないが、表1で示し たように広がりつつある。

しかし、多くの展示会では古典籍の紹介を 印刷体のみで行っている。これは、博物館など で、他の所有者が所蔵するものを展示すること が多いことも影響しているようである。

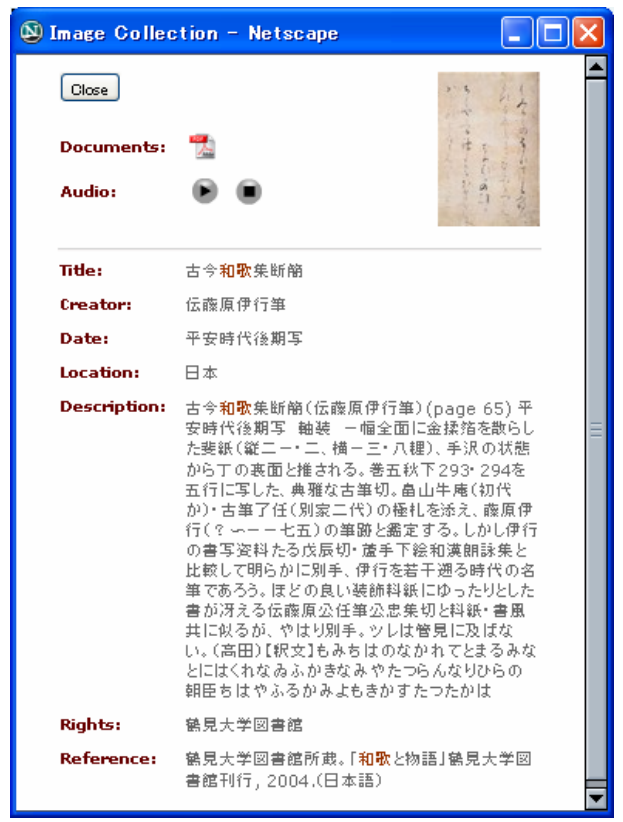

図 1 鶴見大学コレクション (Global Memory Net)

これらの説明文は画像と説明文とが組み合 わされているケースが多いが、説明文のみの ケースもある(表 1 )。

図1のように、筆者の一人は鶴見大学図書 館が所蔵する古典籍や古地図などをデジタル 化し、インターネットで提供するに際して、画像 とともにメタデータを付与して説明文だけより、 内容の理解がし易いようにした ${ }^{4,5}$ 。 


\section{3 メタデータ項目の比較}

表1に示した提供データベースのメタデータ 項目を比較した。

これらのデータベースは基本的なメタデータ 項目の夕からなる文化遺産オンラインや早稲 田大学図書館の「古典籍総合データベース」 などから古典籍に特化した詳細なメタデータが 付与された国文学研究資料館の「古典籍総合 目録データベース」・日本古典資料調查デー タベース」や名古屋大学図書館の「古典籍内 容記述的データベース」まで多様である。多く のデータベースで共通するメタデータとしては (1)「書名」、(2)「著者／作者」、(3)「成立年」、(4) 「形態」などであった。

国文学研究資料館の「日本古典資料調査 データベース」や名古屋大学図書館の「古典 籍内容記述的データベース」ではこの他に書 誌学的な事項からの多くのメタデータが付与さ れていた。

一方で、文化遺産オンラインや Global Memory Netでの鶴見大学コレクションなどで は、他では余り付与されていない「材料/材質」 や地理的区分なども付与されていた。これらと ダブリンコアの基本メタデータセットとの比較も 行った。

\section{4 メタデータの抽出}

比較的多くの古典籍説明文がネット上に掲 載されている鶴見大学図書館の古典籍説明 文からメタデータをマニュアルで抽出した。

本報告で使用した鶴見大学古典籍説明文 は、最近開催された古典籍についての展示会 の際に、来場者への説明のために主として鶴 見大学日本文学科の教員により作成されたも のである。また、一部は出版物として、参加者 に配布されたものもある。

本報告では、「第110回鶴見大学貴重書展 一歌書の版本」、「第109回鶴見大学貴重書展 一曽我物語とその周辺」、「第108回鶴見大
表2 説明文からの抽出メタデータの階層化

(全38レコード)

\begin{tabular}{|c|c|c|c|c|c|}
\hline $\begin{array}{l}\text { 大項目 } \\
\text { 番号 }\end{array}$ & |レベル-1 & |レベル-2 & \begin{tabular}{|l|} 
出現 \\
La- \\
ド数 \\
\end{tabular} & $\begin{array}{l}\text { 全レコー } \\
\text { ド中の } \\
\text { 出現率 }\end{array}$ & $\begin{array}{l}\text { 共通メタ } \\
\text { データ }\end{array}$ \\
\hline \multirow[t]{2}{*}{1} & \begin{tabular}{|l|}
$\begin{array}{l}\text { 書名(タイト } \\
\text { ル) }\end{array}$ \\
\end{tabular} & & 38 & $100 \%$ & \multirow{2}{*}{0} \\
\hline & & $\begin{array}{l}\text { l副書名(サブタイ } \\
\text { トル) }\end{array}$ & 8 & $21 \%$ & \\
\hline \multirow[t]{3}{*}{2} & $\begin{array}{l}\text { 著者/作者/ } \\
\text { 鞬者 }\end{array}$ & & 18 & $47 \%$ & \multirow{3}{*}{ O } \\
\hline & & $\begin{array}{l}\text { 著者/作者/筆者 } \\
\text { の説明 }\end{array}$ & 7 & $18 \%$ & \\
\hline & & $\begin{array}{l}\text { 系統·出版社の } \\
\text { 説明 }\end{array}$ & 12 & $32 \%$ & \\
\hline \multirow{6}{*}{$\frac{3}{4}$} & 所蔵者 & & 6 & $16 \%$ & \multirow[t]{6}{*}{0} \\
\hline & 写本/版本 & & 36 & $95 \%$ & \\
\hline & & 写本の系統 & 4 & - $11 \%$ & \\
\hline & & 版本の種類 & 111 & $29 \%$ & \\
\hline & & 版面 & 2 & $5 \%$ & \\
\hline & & 活字(版本) & 3 & $8 \%$ & \\
\hline \multirow[t]{2}{*}{5} & 成立年 & & 35 & $92 \%$ & \multirow[b]{2}{*}{0} \\
\hline & & $\begin{array}{l}\text { 成立年推定の説 } \\
\text { 明 }\end{array}$ & 3 & $8 \%$ & \\
\hline \multirow[t]{2}{*}{6} & \multirow[t]{2}{*}{\begin{tabular}{|l} 
寸法(表紙 \\
縦 横
\end{tabular}} & & 35 & $92 \%$ & \multirow{2}{*}{0} \\
\hline & & 形態 & 6 & $16 \%$ & \\
\hline \multirow{4}{*}{$\frac{7}{8}$} & 書型 & & 5 & $13 \%$ & \multirow{3}{*}{0} \\
\hline & 数量 (巻数) & & 33 & $87 \%$ & \\
\hline & 装訂 & & 28 & $74 \%$ & \\
\hline & & 装訂の説明 & 19 & $50 \%$ & \\
\hline 10 & 由来 & & 24 & $63 \%$ & \multirow[t]{3}{*}{0} \\
\hline \multirow[t]{2}{*}{11} & \multirow[t]{2}{*}{ 1料紙 } & & 22 & $58 \%$ & \\
\hline & & 料紙の説明 & 5 & $13 \%$ & \\
\hline \multirow[t]{4}{*}{12} & 本の各部 & & 16 & $42 \%$ & \multirow{6}{*}{0} \\
\hline & & 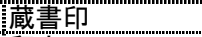 & 1 & $3 \%$ & \\
\hline & & 糈文 & 5 & $\begin{array}{l}13 \% \\
-13\end{array}$ & \\
\hline & & $\begin{array}{l}\text { 極め札: 極め: 折 } \\
\text { 紙 }\end{array}$ & 7 & $18 \%$ & \\
\hline \multirow[t]{2}{*}{13} & \multirow[t]{2}{*}{ 内容の説明 } & & 14 & $37 \%$ & \\
\hline & & 原本の紹介 & 5 & $13 \%$ & \\
\hline 14 & 絵の説明 & & 4 & $11 \%$ & \\
\hline \multirow[t]{3}{*}{15} & 切れ/断簡 & & 6 & $16 \%$ & \\
\hline & & 切れ/斷簡の説 & 6 & $16 \%$ & \\
\hline & & 切れの系統 & 1 & $3 \%$ & \\
\hline \multirow{2}{*}{16} & 塗箱(保存 & & 2 & $5 \%$ & \\
\hline & 参照ページ & & 12 & $32 \%$ & \\
\hline & & & & & \\
\hline & 小区分 & & 38 & $100 \%$ & \\
\hline & 畫風 & & 3 & $8 \%$ & \\
\hline そ & 参考 & & 2 & $5 \%$ & \\
\hline の & 利用目的 & & 1 & $3 \%$ & \\
\hline 他 & $\begin{array}{l}\text { 残存状態 } \\
\text { (残欠) }\end{array}$ & & & & \\
\hline & 叢書合冊 & & & & \\
\hline & 夏録分類 & & & & \\
\hline
\end{tabular}

学貴重書展一物語の古筆切」「第105回鶴見 大学貴重書展示 古今集1100年」、「第99回 鶴見大学 特別展示 古典籍の魅力」の各展 示会からの説明文122件とGlobal Memory Net に収録の109件、合計231件の説明文を使用し た。

古典籍の説明文 231 レコードから、メタデー 夕の解析をするために、各展示会の資料区分 ごとに最低1レコードとなるように、説明文 38 レ 
コードを抽出した。これは、全レコード 231 件の $15 \%$ 強に相当する。

表1の各種データベースのメタデータ項目 から、基本メタデータ項目および古典籍の説 明に必要と考えられる拡張メタデータ項目とを 選択した。表2に示したように、この他に説明 文中より新たなメタデータ項目に適切と思われ る語句も抽出し、新たなメタデータ項目として 追加付与した。

表2に示したように、抽出した全38レコード 中で、各メタデータの付与率が $50 \%$ 以上となる 項目は全41のメタデータ中で、書名 (タイト ル)」、「展示会ごとの区分」、「写本/版本」、 「成立年」、「寸法 (表紙 縦 横)」、「数量 (巻 数) 」、装訂」、「由来」、「料紙」、「装訂の説 明」の合計10項目であった。

これらのメタデータのうち、古典籍の説明に 必要とされる拡張メタデータ項目は、「写本/版 本」、装訂」、「料紙」、装訂の説明」の4つで ある。

そのほかのメタデータで、基本メタデータと 考えられるものは「書名 (タイトル)」、「成立年」、 「法 (表紙 縦 横)」、「数量 (巻数)」、「由 来」などであると判断した。しかし、このうちの 「寸法」や「数量」については、古典籍に即した

\section{参考文献}

［1］秋元 良仁;亀山 渉:「博物館情報を用い た複合的メタデータスキーマ構築手法「フ アジィ・スキーマ」の言語設計」, 情報処理 学会研究報告, Vol.128, pp.25-27, 2006.

[2] 藤沢 仁子;Frederic Andres:"Metadata Integration based on Multi-facet Thesaurus”, 「シソーラスによる複数のメ タデータの統合」, 情報処理学会研究報告, Vo1. 105, pp. 33-40, 2005.

[3] 木下 慶子;村上 敦志;稲積 泰宏;森住 哲也;木下 宏:「デジタルアーカイブにおけ るOntologyの活用」電子情報通信学会技 術研究報告. Vol.105, No.466, pp. 1-6, 2005.

[4] Nagatsuka, Takashi; Chen, Ching-chih:
サイズの計測、あるいは数量で巻数など固有 の単位が必要となる項目である。また、「由来」 も古典籍に即した内容となり、単一の語句であ らわすには難しく、多くの場合に説明文中に文 章で由来についての説明がなされている。

\section{5 まとめ}

今回の検討サンプルである鶴見大学古典 籍説明文から、「展示会ごとの区分」、「本の各 部」、「内容の説明」、「参照ページ」、「系統・ 出版社の説明」、「版本の種類」、「料紙の説 明」、「書型」、「写本の系統」、「絵の説明」、 「成立年推定の説明」、「活字 (版本) 」、「塗箱 (保存用の箱)」、「切れの系統」の14項目を本 説明文の解析から新たなメタデータとして抽出 できた。

説明文からのメタデータをグループ化し、 メタデータ間の階層関係について検討したとこ ろ、基本的な古典籍の形態である「写本」「版 本」、「切れ」および「その他資料」の間で、付 与されたメタデータが異なり、それぞれの古典 籍の形態が反映されていることが明らかとなっ た。

\footnotetext{
"Global Memory Net Offers New Innovative Access to Tsurumi's Old Japanese Waka Poems and Tales, and Maps”, In the Proceedings of the eighth International Conference on Asian Digital Libraries (ICADL2005), Springer, LNCS3815, pp.149-157, 2005.

[5] Egusa ,Yuka; Nagatsuka, Takashi:” New innovative access to educational and cultural multimedia contents", World Library and Information Congress: 72nd IFLA General Conference and Council(Seoul) http://www.ifla.org/IV/ifla72/papers/097 -Egusa_Nagatsuka-en.pdf, 2006.
} 